UDC 94(477.83)«1939-1944»

DOI: doi.org/10.21272/shaj.2018.i30.p32.

MYKOLAD.HALIV

Drohobych Ivan Franko State Pedagogical University, PhD (Education), Associate Professor (Ukraine)

\title{
THE REORGANIZATION OF EDUCATION IN DROHOBYCH LAND IN 1939-1944: A COMPARATIVE ANALYSIS OF SOVIET AND GERMAN PRACTICES ${ }^{1}$
}

Abstract. In the article the policy of Hitlerite and Stalin regimes concerning the reorganisation of education on the lands of Drohobych region of the Ukr.SSR in 1939-1944. The topicality of the theme is caused by an increase of the attention of scientists to the comparative researches on the totalitarian regimes of the XX century. In particular, it is - as far as the author's belief can make out - most effective in the application to narrow territorial and time measurements. Under such circumstances it gives the chance to in more details and contextually more fully to analyze concrete mechanisms of functioning of totalitarian regimes in different spheres of public life, particularly - in education.

The comparative analysis done has captured the next aspects: management of education, a network of schools, pedagogical cadres, the student's contingent, professional and higher education, education of adults and the course system of training, the content of education and training. It has been found out that the Nazi educational policy was more destructive in the institutional and personal measurements. Especially, the school network was reduced, almost all secondary schools and the only higher educational institution, namely, Drohobych Teachers' Training Institute were liquidated, the number of teachers and pupils decreased, and the material maintenance of teachers also considerably worsened. At the same time, the German education authorities had much less possibilities for the controlling functions, than a widely developed Soviet administrative network. Hence, in the years of the Nazi occupation the public access to certain links of education grew, first of all, to preschool centres and after-school establishments. Among the positive sides of education of the Soviet period the author observes a substantially grown number of the Ukrainian language schools and attraction of almost all the children to school education process, while in the Nazi period a wide development of professional schooling is to be taken into reflexion.

The author underlines, that there was no catastrophic fall in the education system even in the hard time of the Hitlerite occupation, and the local public, - both Ukrainian and Polish, executed all possible efforts (certainly, within the measures defined by the Nazis) for the preservation of the national educational traditions.

Keywords: comparative analysis, education system, totalitarian regime, Drohobych region, 1939-1944.

ГАЛІВ М.Д.

Дрогобицький державний педагогічний університет імені Івана Франка, кандидат педагогічних наук, доцент (Україна)

\section{РЕОРГАНІЗАЦІЯ ОСВІТИ НА ДРОГОБИЧЧИНІ В 1939-1944 РР.: ПОРІВНЯЛЬНИЙ АНАЛІЗ РАДЯНСЬКИХ І НІМЕЦЬКИХ ПРАКТИК}

\footnotetext{
Анотація. У статті порівнюється політика гітлерівського та сталінського режимів щодо реорганізації освіти на теренах Дрогобиџької області УРСР у 1939-1944 рр. Порівняльний аналіз охопив такі аспекти: управління освітою, мережа шкіл, педагогічні кадри, учнівський контингент, фахова і вища освіта, освіта дорослих та курсова система навчання. Встановлено, що нацистська освітня політика була більш руйнівною в інститучійному та особистісному вимірі, однак відзначалася меншим контролюючим потенціалом. До позитивних сторін освіти у радянський період автор зараховує
} 
збільшення кількості украӥномовних шкіл, залучення значного числа дітей шкільного віку до школи, в нацистський - широку розбудову фахового шкільництва.

Ключові слова: порівняльний аналіз, система освіти, тоталітарний режим, Дрогобицька область, 1939-1944 рр.

ГАЛИВ Н.Д.

Дрогобычский государственный педагогический университет имени Ивана Франко, кандидат педагогических наук, доцент (Украина)

\section{РЕОРГАНИЗАЦИЯ ОБРАЗОВАНИЯ НА ДРОГОБЫЧЧИНЕ В 1939-1944 ГГ.: СРАВНИТЕЛЬНЫЙ АНАЛИЗ СОВЕТСКИХ И НЕМЕЦКИХ ПРАКТИК}

Аннотация. В статье сравнивается политика гитлеровского и сталинского режимов по реорганизации образования на территории Дрогобычской области УССР в 1939-1944 22. Сравнительный анализ охватил такие аспекть:: управление образованием, сеть школ, педагогические кадры, ученический контингент, профессиональное и высшее образование, образование взрослых и курсовая система обучения. Установлено, что нацистская образовательная политика была более разрушительной $в$ институицональном и личностном измерении, однако отмечалась менее контролируюющчм потенцииалом. K положительным сторонам образования в советский период автор относит увеличение количества украиноязычных школ, привлечение значительного числа детей школьного возраста в школу, в нацистский - широкое распространение профессиональных икол.

Ключевые слова: сравнительный анализ, система образования, тоталитарный режим, Дрогобычская область, 1939-1944 г2.

Дослідження природи тоталітарних режимів XX ст., їх утворення, структурованості, різних аспектів функціонування і наслідків найчастіше спирається на порівняльноісторичний метод. Він дає змогуз'ясувати не лише схожі та відмінні риси тоталітаризмів, але виявити об'єктивні та субєктивні передумови їх формування, ідеократичні чинники, еволюційні закономірності та трансформації. Особливо ефективним, на наше переконання, цей метод $є$ у вузьких територіальних та часових вимірах, оскільки дає змогу більш деталізовано і фактологічно аналізувати конкретні механізми функціонування тоталітарних режимів у різних сферах суспільного життя, зокрема освіті. 3 огляду на це вважаємо актуальною спробу порівняти освітню політику радянського і нацистського тоталітарних режимів на теренах Дрогобицької області України у 1939-1944 p.

Порівняльні студії тоталітарних режимів набули поширення після Другої світової війни у працях філософів, істориків та політологів (М. Бон, Х. Ортега-і-Гассет, Х. Арендт, Е. Нольте, П. Дракер, К. Фрідріх, 3. Бжезинський, І. Дейчер, Л. Шапіро, М. Кертіс, Р. Арон, Ю. Давидов, В. Ільїн, К. Гаджієв та ін.). Серед українських дослідників одним із перших, хто компаративно проаналізував фашистський, нацистський і сталінський тоталітарні режими, був Б. Дем'яненко (Дем'яненко, 2000). Порівняльний аналіз діяльності радянського і нацистського режимів в Галичині у роки Другої світової війни здійснили Г. Марискевич та І. Гаврилів (Марискевич, Гаврилів, 2009). Однак порівняльного аналізу політики двох режимів у сфері освіти західноукраїнських земель наразі не здійснено.

Мета статті - порівняти політику гітлерівського та сталінського режимів щодо реорганізації освіти на теренах Дрогобицької області УРСР у 1939-1944 pp.

Протягом 1939-1944 pр. на теренах Дрогобицької області УРСР відбулися зумовлені геополітичними чинниками значні зміни суспільного життя. Трансформацій зазнала й система освіти (дошкілля, загальноосвітня, середня спеціальна, вища школи, освіта 
дорослих тощо), яку сталінський та гітлерівський тоталітарні режими намагалися використати у своїх цілях - формально різних, але, по суті, однакових. При цьому обидва тоталітаризми намагалися відсторонити національні сили від формування освітнього процесу, повністю підпорядкувавши його власним потребам.

Радянська влада на Дрогобиччині доволі швидко сформувала ідентичну з рештою регіонів СРСР структуру управління освітою: обласний, міські та районні відділи народної освіти (останніх налічувалося 29). Майже вся управлінська номенклатура формувалася з надісланих зі східних областей УРСР, а також РРФСР партійних та радянських діячів (Bonusiak, 2006: 60-61, 301; Галів, 2010: 11). Подібним чином діяли й нацисти, розбудувавши протягом двох-трьох місяців після початку окупації адміністративний апарат. Терени Дрогобицької області увійшли до складу дистрикту “Галіція” (Дрогобицька, Стрийська, Самбірська округи, частина округи Львів-повіт) та Краківського дистрикту (частина Перемишльської округи). У кожній окрузі діяв “шкільний уряд” (шульамт) на чолі з надісланим із Генеральної губернії (далі - ГГ) чи рейху шкільним радником (крейсшульрат), якому підпорядковувалися шкільні інспектори, що добиралися з місцевих освітян (Адміністраційний поділ, 1941: 2; Декрет, 1941: 91). Обидві структури управління реформували систему освіти, маючи на меті сформувати повністю підконтрольну істоту, працівника-раба, яким можна легко маніпулювати задля досягнення ідеологічно обгрунтованих політичних цілей.

Щоправда, спостерігалися й значні відмінності у підходах побудови освітньовиховного механізму. Якщо більшовики перетворили всі ланки системи освіти в єдиний державний інститут, то нацисти окремі ії складові залишили у віданні “колаборантських" організацій, певною мірою допускаючи їх до формування змісту навчально-виховного процесу, його матеріального забезпечення. Так, у 1939-1941 рр. радянською владою було повністю одержавлено дошкілля й створено у Дрогобицькій області понад 50 постійних дитячих садків для 2,3 тис. малят (Народне господарство, 1958: 185). Натомість у період німецької окупації дошкіллям займалися місцеві громади, окружні (українські та польські) допомогові комітети, церкви (Антонюк, 1997: 30). Кількість українських постійних садків протягом 1942 р. сягнула 45. Особливого ж поширення набуло сезонне дошкілля. У чотирьох округах (Дрогобицькій, Самбірській, Стрийській та Перемишльській, що становили більшість території окупованої Дрогобицької області) на 1942 р. діяло 397 українських сезонних дитсадків. Наступного року їх кількість зросла (принаймні на Дрогобиччині і Стрийщині) (Галів, 2010: 113).

Прагнучи забезпечити масовість освіти молоді, радянська влада значну увагу приділяла розбудові шкільної сітки, водночас перетворюючи старі загальноосвітні навчальні заклади (триступеневі народні школи, гімназії та ліцеї) у початкові (чотирирічні), неповні середні (семирічні), середні (десятирічні) школи. Вдалося збільшити чисельність загальноосвітніх навчальних закладів, змінити національний спектр шкільництва на користь місцевої української більшості. У 1938/39 навчальному році на теренах Львівського і Станіславського воєводств, які пізніше увійшли до складу Дрогобицької області, налічувалося 642 школи, більшість із них - утраквістичні. На початку ж 1940/41 навчального року в області діяло 916 шкіл, з них 817 україномовних (Народне господарство, 1958: 177). Під час гітлерівської окупації у Дрогобицькій, Самбірській та Стрийській округах функціонувало понад 620 початкових шкіл (приблизно 504 українських, 90 польських, 27 німецьких) та 2 українські гімназії в Дрогобичі та Стрию (Галів, 2010). 3 огляду на брак джерел, невідомою залишається чисельність шкіл інших районів колишньої Дрогобицької області УРСР. Однак припускаємо, що початково під німецькою окупацією чисельність народних та середніх шкіл сягала принаймні 800. Відомо, що після відновлення радянської влади у вересні-жовтні 1944 р. швидко змогли 
відновити роботу 864 школи Дрогобицької області, з них 465 початкових (усі в селах), 356 неповних середніх (24 у містах, 332 в селах) і 43 середні (30 у містах, 13 в селах) (ЦДАВОВУ України. Ф. 166. Оп. 15. Спр. 24. Арк. 26). Тож шкільна мережа часів окупації ненабагато поступалася попередньому “радянському” періоду. Проте слід враховувати, що гітлерівцями було ліквідовано всі єврейські та російські школи, закрито польські і більшу частину українських десятирічок (або ж понижено їх до рівня початкових шкіл), натомість створено декілька десятків німецькомовних освітніх установ початкового рівня. Згодом шкільна мережа поступово зменшувалася за рахунок закриття переважно українських і частково польських шкіл (Галів, 2010: 131).

Специфічною була політика обох тоталітарних режимів щодо педагогічних кадрів загальноосвітніх шкіл. Зусилля освітніх органів радянської влади були спрямовані на зростання чисельності вчителів, підвищення їх кваліфікації, а також на ідейнополітичне виховання в комуністичному дусі. На роботу було залучено понад 2 тис. місцевих безробітних учителів, приблизно 760 педагогів надіслано зі східних областей УРСР (Кошарний, 250). Тож на початок 1940/41 навчального року кількість учителів загальноосвітніх шкіл Дрогобицької області становила 5291, напередодні німецькорадянської війни зросла, можливо, до 5400 (за іншим даними - понад 5900) осіб (Народна освіта, 1967: 91; ДАЛО. Ф. 5001. Оп. 2. Спр. 21. Арк. 71). Широко запроваджувалися такі форми підвищення кваліфікації педагогів, як взаємовідвідування уроків, “кущові” семінари, учительські районні та обласні конференції, курси узаснованому в лютому 1940 р. обласному інституті удосконалення кваліфікації учителів тощо. Попри це, основна увага все ж приділялася піднесенню ідейно-політичного рівня вчителів (Głowacki, 1998: 435).

У період німецької окупації кількість педагогів різко зменшилася. Школи лише трьох округ (Дрогобицької, Стрийської і Самбірської) на 1941/42 навчальний рік налічували приблизно 1400-1450 учителів (враховуючи і педколективи двох гімназій). 3 часом їх ставало дедалі менше, причиною чого було, передовсім, важке матеріальне становище рядового вчителя. Зрештою, за даними С. Сворака, на час відновлення радянського режиму (серпень 1944 р.) на теренах Дрогобицької області залишилося всього 1807 педагогів (можливо, що у це число зарахували і викладачів професійних шкіл) (Сворак, 1998: 68). Попри важке становище, учителі все ж працювали над удосконаленням свого професійного рівня, брали участь у різноманітних педагогічно-методичних заходах (окружних та “районних" конференціях, відкритих уроках та ін.), що організовувалися, зокрема, за активної участі Українського учительського об'єднання праці.

Протягом 1939-1944 рр. відбулися різкі коливання у кількісному та етнічному складі учнівського контингенту загальноосвітніх шкіл. Завдяки зусиллям радянських властей, що боролися за масовість освіти дітей та молоді, а відтак і масовість їх комуністичного виховання, чисельність учнів загальноосвітніх шкіл Дрогобицької області УРСР поступово зростала. У вересні-жовтні 1939 р. на теренах, що згодом увійшли до складу області, налічувалося 158 тис. школярів (Кошарний, 1957: 249). На кінець 1940/41 навчального року їх число зросло до понад 193 тис. осіб (Кошарний, Підпригорщук та ін., 1957: 170). 3'ясувати етнічний спектр школярів Дрогобиччини доволі важко. Вважаємо, що на початку 1940/41 навчального року кількість учнів-поляків та євреїв у загальноосвітніх школах області не перевищувала 14,7\% і становила майже 25 тис. осіб. Протягом німецької окупації чисельність учнів початкових і середніх шкіл Дрогобицької, Самбірської, Стрийської округ сягала 100 тис. осіб, більшу частину з яких становили школярі-українці (понад 80 тис.) (Галів, 2010: 162). Попри відсутність даних з решти територій колишньої Дрогобицької області УРСР, можна упевнено твердити про значно меншу чисельність учнів, порівняно з попереднім, “радянським” періодом. Ще нижчою виявилася шкільна 
фриквенція, що пояснюється і важким матеріальним становищем населення, і епідеміями хвороб, і невисоким авторитетом тогочасної школи.

Порівняння змістових особливостей навчально-виховного процесу шкіл Дрогобиччини окресленого періоду виявляє значну відміність у цьому аспекті. Радянська влада, запровадивши у 1939/40 навчальному році “новий” навчальний план, змушена була брати до уваги мовнонаціональну форму шкіл, а отже, виділяти певну кількість годин для вивчення рідної мови та літератури, при цьому залишаючи найбільшу серед навчальних предметів кількість урочного часу для вивчення власне російської мови та літератури. Ліквідовувалося викладання релігії, історії та географії Польщі, натомість запроваджувалися традиційні для радянської школи “ідеологічні” предмети: історія СРСР, конституція СРСР та УРСР тощо (Інструкція, 1940: 5-6, 8-9). Методика навчання школярів також переводилася на апробовані в Радянському Союзі засади і включала, зокрема, розпропаговану “боротьбу” за успішність (що нерідко призводила до штучного завищення оцінок) та відвідування учнів. Зміст навчального матеріалу, особливо гуманітарних предметів, характеризувався вихолощенням національної складової і впровадженням класово-комуністичних постулатів. Виховні завдання комуністичного гатунку реалізовувалися за допомогою таких форм роботи: масові урочисті заходи, доповіді, бесіди, участь у театральних виставах, відвідування відповідних кіносеансів, видання спеціальних номерів шкільних газет, організація політичних та атеїстичних читань, підготовка відповідних альбомів, творення кутків вільнодумства та гуртків безбожників тощо. Проте новій владі за такий короткий відрізок часу не вдалося повністю розгорнути в регіоні систему комуністичного виховання, а відтак досягнути відповідної трансформації свідомості молоді.

Навчально-виховний процес місцевого шкільництва періоду німецької окупації визначався нацистськими дискримінаційними підходами щодо освіти підкореного населення. Вони полягали у примітивізації навчальної програми, з якої було еліміновано основні гуманітарні предмети (історія, географія, рідна література) (Стефанюк, 2002: 25). Щоправда, останні все ж вивчалися у гімназіях, де, однак, найбільша кількість навчального часу відводилася для опанування німецької, української та латинської мов. За цих умов і українські, і польські освітяни прагнули дати учням гідну освіту, виховати їх на засадах християнських та національних цінностей. Це вдавалося робити й у межах шкільного навчально-виховного процесу, і поза навчальним закладом - у рамках осередків Українського освітнього товариства та польського “таємного навчання”. Учні ж німецьких шкіл опинилися під цілковитим тиском нацистської педагогіки, притаманної їй антигуманної системи цінностей та організаційних форм.

Досліджено матеріальне забезпечення загальноосвітніх шкіл. Більшовицькі власті, націоналізувавши приватні та перейнявши державні навчальні заклади, змушені були витрачати величезні кошти на їх утримання. Уже в 1940 р. приблизно 60\% бюджету області скеровувалося на культурно-освітні потреби місцевого населення (Кошарний, 1957: 251). На жаль, у процесі дослідження наявних матеріалів не виявлено, скільки грошей призначалося конкретним школам, однак вони постійно відчували проблеми 3 налагодженням харчування учнів, забезпеченням навчальною літературою тощо. Зрештою, радянській владі так і не вдалося за короткий термін забезпечити заклади освіти підручниками, передовсім польськомовними (Głowacki, 1998: 429).

Утримання загальноосвітніх шкіл у 1941-1944 pр. було розподілено між окупаційною адміністрацією (у тому числі міськими та сільськими управами) та допомоговими комітетами. Перші сплачували заробітну платню вчителям і допоміжним працівникам, фінансували ремонтні роботи, опалення, освітлення тощо, інші піклувалися про харчування учнів, стипендію для гімназистів тощо. Видатки на кожну конкретну школу 
залежали від якісного та кількісного стану її матеріальної бази. Зазвичай, на покриття потреб кожної міської школи, наприклад, у Дрогобичі, передбачалося 8-12 тис. зл. щорічно (ДАЛО. Ф. Р-1951. Оп. 1. Спр. 132. Арк. 6, 9, 58-58зв, 85-87). Проте у важких умовах воєнного часу та окупаційної політики шкільні бюджети, зазвичай, не виконувалися. Крім недостатньої грошової підтримки вкрай незадовільним рівнем характеризувалося постачання підручниками, яке для польських і значною мірою українських шкіл майже не проводилося.

Співставлення позашкільних систем навчання і виховання учнівської молоді на Дрогобиччині показує, що протягом 1939-1941 рр. радянській владі вдалося організувати розгалужену мережу позашкільних навчально-виховних закладів та установ. До їх складу належали музичні школи (Дрогобич, Стрий, Самбір, Перемишль), 23 дитячі будинки i школи для осіб із психофізичними вадами (наприклад, сиротинці в Дрогобичі, Бориславі, школа для незрячих у с. Калинів Дублянського району), Палац і клуби піонерів (в обласному і районних центрах), піонерські табори (зокрема, у с. Старява Хирівського району) тощо. Їх завданням було зайняти майже весь зайвий час учнів, використавши його для забезпечення “правильного” виховного впливу. На це й спрямовувалася широка серія позашкільних виховних заходів на зразок олімпіад художньої самодіяльності, спортивних змагань на здобуття ступенів “Будь готовий до праці та оборони” та "Готовий до праці та оборони” тощо. Німецькі ж окупаційні власті дозволяли організовувати позашкільну діяльність підконтрольним громадським організаціям, передовсім окружним допомоговим комітетам. Система позашкільного навчання та виховання дітей і молоді Дрогобиччини у 1941-1944 рр. репрезентувалася: а) сезонними дитячо-юнацькими таборами (у Старому Самборі, селах Розлуч, Корчин, Синевідсько Вижнє, Славсько); б) сирітськими притулками (Дрогобич, Самбір, Сколе та ін.); в) дитячими гуртками при референтурах опіки над молоддю і родиною Українських окружних комітетів (наприклад, при Самбірському УОК) (Цьогорічні табори, 1942: 142; Літній відпочинок, 1943: 6; ДАЛО. Ф. Р-1948. ОП. 1. Спр. 12. Арк. 1-4).

Обидва режими - радянський та нацистський - значну увагу приділяли розбудові фахового шкільництва, оскільки були особливо зацікавлені у підготовці кваліфікованих робітників. За нашими підрахунками, у 1939-1941 рр. на теренах Дрогобицької області діяло не менше 24 спеціальних навчальних закладів різного рівня та професійного спрямування. Переважна більшість з них працювали на базі реорганізованих як приватних, так і державних профшкіл, що залишилися з довоєнного часу. Утворювалися й нові для західноукраїнських земель навчальні заклади, зокрема школи ФЗН. Із деякими застереженнями (відсутність даних щодо чисельності студентів щонайменше 8 з 24 СН3) уважаємо, що кількість студентів професійних освітніх установ Дрогобиччини становила понад 3 тис. осіб (Галів, 2010: 232).

Окрім профшкіл радянськими властями було утворено і єдиний на теренах Дрогобицької області УРСР вищий навчальний заклад - Дрогобицький державний учительський інститут. Протягом 1940 - першої половини 1941 рр. відбувалося становлення матеріально-технічної бази інституту, комплектування професорськовикладацького складу (10 осіб на чолі з директором А. Туманом), формування студентського контингенту (приблизно 670 осіб, що навчалися на денній, заочній та вечірній формах навчання), налагодження навчально-виховного процесу (Туман, 1941: 1).

Німцями було ліквідовано учительський інститут, але створено більш широку мережу фахових шкіл промислово-ремісничого, торговельного та сільськогосподарського спрямування. Вони поділялися на три ступені: обов'язкові (призначені винятково для підвищення професійної кваліфікації й рівня фахової освіти молоді, яка працювала на промислових, ремісничих, торговельних підприємствах та у сільському господарстві), 
званеві, фахові (вищого ступеня). Зазвичай створювалися україномовні та польськомовні школи, часто окремо для юнаків та дівчат (хоч діяли й коедукаційні заклади). На основі існуючих й проаналізованих матеріалів стверджуємо, що у 1943 р. на теренах колишньої Дрогобицької області було утворено приблизно 30 профшкіл (без обов'язкових сільськогосподарських), де освіту здобувало майже 5 тис. учнів. Обов'язкові ж сільськогосподарські школи, що засновувалися майже в кожній волосній громаді, були найбільш поширеними і масовими навчальними закладами. Наприклад, лише у Дрогобицькій та Самбірській округах на другу половину 1942 р. діяло 22 такі школи, у кожній з яких навчалося від 70 до понад 300 учнів (Галів, 2010: 233). Зауважимо, що обов'язкові школи вважалися приватними і фінансувалися місцевими управами, союзами громад й окружними комітетами, натомість званеві та фахові школи перебували на утриманні держави. Найбільш відомими професійними навчальними закладами вищого (фахового) рівня на теренах окупованої області були: українська (з польськими класами) технічна школа у Дрогобичі, українська і польська торговельні школи у Дрогобичі, бурильно-технічна (з польськими та українськими класами) школа у Бориславі, українська хімічно-технічна фахова школа в Перемишлі. Загалом, порівняно з довоєнним часом, кількість фахових шкіл, передовсім українських, значно зросла, що обумовлювалося політикою окупаційної влади, яка передбачала надання населенню підкорених земель можливості здобути тільки початкову і професійну освіту, ліквідацію нестачі кваліфікованих працівників у різних сферах господарського життя, перспективу вивезення на роботу до рейху.

Схожими були заходи влади у справі організації освіти дорослих і курсової системи навчання. Більшовики доволі швидко створили розгалужену систему різних типів навчальних установ для дорослих: шкіл і гуртків з ліквідації анальфабетизму (до кінця 1939 р. у Дрогобицькій області діяло 465 шкіл з ліквідації неписьменності, які охоплювали 19700 осіб, та 150 шкіл для малописьменних, де навчалося 4 тис. осіб), вечірніх шкіл (8 середніх та 24 семирічних), фахових курсів та гуртків підвищення кваліфікації (Кошарний, Підпригорщук та ін., 1957: 171). Потреба у них диктувалася як практичною необхідністю (наприклад, у Дрогобицькій області наприкінці 1939 р. налічувалося 181 тис. неписемних) (Кошарний, 1957: 252-253), так і ідеологічно-політичними міркуваннями. Попри сприяння загальному та професійному освітньому рівню місцевого дорослого населення, вечірні школи, різноманітні курси, гуртки лікнепу були вагомим засобом комуністичної індоктринації. На сьогодні є всі підстави вважати, що оголошені владою та підхоплені радянськими істориками твердження про успішні результати, наприклад, подолання неписьменності серед дорослих, є доволі сумнівними.

Протягом німецької окупації залишилася єдина форма здобуття і покращення освіти дорослих - курсова система навчання, яка набула значного поширення в краї. Ініціативу та організаційні зусилля у справі проведення різноманітних курсів виявляли переважно різні, дозволені владою громадські та господарські організації- українські, польські і навіть єврейські (юденрат). Лише зрідка проведення певних курсів ініціювали німецькі владні органи. Загалом діяло три різновиди курсів: 1) для осіб, зайнятих у сільському господарстві та ремісництві; 2) для чиновників та службовців; 3) для працівників соціальногуманітарної (освітньої, просвітницької, медичної) сфери. 3 огляду на соціальноекономічну специфіку краю, переважали сільськогосподарські курси та курси домашнього господарства. Поширеними були курси німецької мови, які призначалися здебільшого для місцевих службовців державних установ і громадських організацій. Останні вдавалися й до проведення курсів соціально-гуманітарного характеру, спрямованих на підготовку педагогів, садівничок, просвітян (диригентів хорів, керівників самоосвітніх гуртків, бібліотекарів тощо) та працівників нижньої ланки медичної сфери (санітарок). У 
цілому ж курсова система була вагомою можливістю здобути додаткові та покращити професійні знання для дорослих осіб, що з різних причин не мали змоги здобути освіту у фахових навчальних закладах.

Отже, система освіти Дрогобиччини у 1939-1944 рр. двічі зазнавала серйозної перебудови, спочатку на радянський зразок, пізніше відповідно до офіційної політики керівництва ГГ. На нашу думку, не можна однозначно оцінювати ці зміни, трактувати їх винятково з негативного чи позитивного боку. Попри значні мінуси, тогочасна система освіти мала й окремі позитиви: у радянський період - збільшення кількості україномовних шкіл, залучення значного числа дітей шкільного віку до школи, в нацистський - широка розбудова фахового шкільництва. Важливо усвідомити, що катастрофічного занепаду в системі освіти не відбулося навіть у важкий час гітлерівської окупації, а місцева громадськість - і українська, і польська - докладали всіх можливих зусиль (звісно, у дозволених нацистами рамках) для збереження національних освітніх традицій.

${ }^{1}$ Публікація містить результати досліджень, проведених при грантовій підтримці Державного фонду фундаментальних досліджень за конкурсним проектом Ф77/80 - 2017.

\section{Лiтература:}

Адміністраційний поділ, 1941 - Адміністраційний поділ Галицької області // Вільне слово. 1941. № 35-36. C. 2 .

Антонюк, 1997 - Антонюк Н. В. Українське культурне життя в Генеральній Губернії (1939-1944 роки). Львів, 1997. $232 \mathrm{c.}$

Галів, 2010 - Галів М. Між серпомолотом і свастикою: освіта на Дрогобиччині у 1939-1944 pp. Дрогобич, 2010.337 с.

Декрет, 1941 - Декрет про зміну границь між Областями Кракав та Галичина (з дня 7 серпня 1941)// Денник Розпорядків для Генерального Губернаторства. 1941. Ч. 32. С. 91.

Дем'яненко, 2000 - Дем'яненко Б.Л. Три моделі тоталітаризму: порівняльний аналіз фашизму, більшовизму та націонал-соціалізму. Київ: Нелень, 2000. 254 с.

ДАЛО - Державний архів Львівської області.

Інструкція, 1940 - Інструкція про порядок реорганізації шкіл в західних областях Української РСР.

Київ: Управління шкіл НКО УРСР, 1940. 20 с.

Кошарний, Підпригоршук та ін., 1957 - Кошарний I.Я., Підпригоршук М.В., Гапшенко I.I., Скрипник

К.І. Радянська Дрогобиччина. Дрогобич: Дрогобицьке обласне вид-во, 1957. 202 с.

Кошарний, 1957 - Кошарний І.Я. Культурне будівництво на Дрогобиччині в 1939-1941 роках // 40 років Великого Жовтня. Львів, 1957. С. 246-262.

Кошарний, 1975 - Кошарний І.Я. У сузір'ї соціалістичної культури. Культурне будівництво у возз'єднаних областях Української РСР (1939-1958 рр.). Львів: Вища школа, 1975. 238 с.

Літній відпочинок, 1943 - Літній відпочинок молоді. Юнацькі табори в Скільщині // Голос Підкарпаття. 1943. Ч. 29. С. 6.

Марискевич, Гаврилів, 2009 - Марискевич Г., Гаврилів І. Галичина в роки Другої світової війни: порівняльний аналіз окупаційних режимів // Мандрівець. 2009. № 3 . С. 47-53.

Народна освіта, 1967 - Народна освіта та педагогічна наука в Українській РСР (1917-1967). Київ: Рад. школа, 1967. 482 c.

Народне господарство, 1958 - Народне господарство Української РСР. Статистичний щорічник. 1957 рік. К.: Держстатвидав, 1958. $254 \mathrm{c}$.

Сворак, 1998 - Сворак С.Д. Народна освіта у західноукраїнському регіоні: історія та етнополітика (1944-1964 рр.). Київ: Правда Ярославичів, 1998.239 с.

Стефанюк, 2002 - Стефанюк Г. Українська школа в політичних планах німецької окупаційної адміністрації в 1941-1944 рр. // Людина і політика. 2002. № 2. С. 19-28. (426). C. 1.

Туман, 1941 - Туман А. Рік роботи учительського інституту // Більшовицька правда. 1941. № 76

ЦДАВОВУ України - Центральний державний архів вищих органів влади та управління України.

Цьогорічні табори, 1942 - Цьогорічні табори молоді // Дорога. 1942. Ч. 10. С. 142.

Głowacki, 1998 - Głowacki A. Sowieci wobec polaków na ziemiach wschodnich II Rzeczypospolitej. Wydanie II. Lódź: Wydawnictwo Uniwersytetu Lódźkiego, 1998. $695 \mathrm{~s}$.

Bonusiak, 2006 - Bonusiak W. Polityka ludnościowa i ekonomiczna ZSRR na okupowanych ziemiach polskich w latach 1939-1941 ("Zachodnia Ukraina" i "Zachodnia Białoruś"). Rzeszów: Wyd-wo Uniwersytetu Rzeszowskiego, 2006. $475 \mathrm{~s}$. 
References:

Administratsiinyi podil, 1941 - Administratsiinyi podil Halytskoi oblasti [Administrative division of Halychyna region]. Vilne slovo. 1941. № 35-36. P. 2. [in Ukrainian].

Antoniuk, 1997 - Antoniuk N. V. Ukrainske kulturne zhyttia v Heneralnii Hubernii (1939 - 1944 roky) [Ukrainian cultural life in the General Province (1939-1944)]. Lviv, 1997. 232 s. [in Ukrainian].

Haliv, 2010 - Haliv M. Mizh serpomolotom i svastykoiu: osvita na Drohobychchyni u 1939-1944 rr. [Between the sickle/hammer and the swastika: education in Drogobych region in 1939-1944.]. Drohobych, 2010. 337 s. [in Ukrainian].

Dekret, 1941 - Dekret pro zminu hranyts mizh Oblastiamy Krakav ta Halychyna (z dnia 7 serpnia 1941) [Decree on the change of boundaries between the Krakiv and Halychyna regions (from August 7, 1941)]. Dennyk Rozporiadkiv dlia Heneralnoho Hubernatorstva. 1941. Ch. 32. P. 91. [in Ukrainian].

Demianenko, 2000 - Demianenko B.L. Try modeli totalitaryzmu: porivnialnyi analiz fashyzmu, bilshovyzmu ta natsional-sotsializmu [Three models of totalitarianism: a comparative analysis of fascism, bolshevism, and national-socialism]. Kyiv: Nelen, 2000. 254 s. [in Ukrainian].

DALO - Derzhavnyi arkhiv Lvivskoi oblasti [State Archive of Lviv region]. [in Ukrainian and German].

Instruktsiia, 1940 - Instruktsiia pro poriadok reorhanizatsii shkil v zakhidnykh oblastiakh Ukrainskoi RSR [The instruction on the order of reorganization of schools in the western regions of the Ukrainian SSR]. Kyiv: Upravlinnia shkil NKO URSR, 1940.20 s. [in Ukrainian].

Kosharnyi, Pidpryhorshchuk etc., 1957 - Kosharnyi I.Ya., Pidpryhorshchuk M.V., Hapshenko I.I., Skrypnyk K.I. Radianska Drohobychchyna [Soviet Drohobych region]. Drohobych: Drohobytske oblasne vyd-vo, 1957. $202 \mathrm{~s}$. [in Ukrainian].

Kosharnyi, 1957 - Kosharnyi I.Ya. Kulturne budivnytstvo na Drohobychchyni v 1939-1941 rokakh [Cultural construction in Drogobych region in 1939-1941]. 40 rokiv Velykoho Zhovtnia. Lviv, 1957. Pp. 246-262. [in Ukrainian].

Kosharnyi, 1975 - Kosharnyi I.Ya. U suziri sotsialistychnoi kultury. Kulturne budivnytstvo u vozziednanykh oblastiakh Ukrainskoi RSR (1939-1958 rr.) [In the constellation of socialist culture. Cultural construction in the reunited regions of the Ukrainian SSR (1939-1958)]. Lviv: Vyshcha shkola, 1975. 238 s. [in Ukrainian].

Litnii vidpochynok, 1943 - Litnii vidpochynok molodi. Yunatski tabory v Skilshchyni [Summer holiday for youth. Youth camps in the Skole district]. Holos Pidkarpattia. 1943. Ch. 29. P. 6. [in Ukrainian].

Maryskevych, Havryliv, 2009 - Maryskevych H., Havryliv I. Halychyna v roky Druhoi svitovoi viiny: porivnialnyi analiz okupatsiinykh rezhymiv [Galicia during the Second World War: a comparative analysis of the occupation regimes]. Mandrivets. 2009. № 3.pp. 47-53. [in Ukrainian].

Narodna osvita, 1967 - Narodna osvita ta pedahohichna nauka v Ukrainskii RSR (1917-1967) [Public education and pedagogical science in the Ukrainian SSR (1917-1967)]. Kyiv: Rad. shkola, 1967. 482 s. [in Ukrainian].

Narodne hospodarstvo, 1958 - Narodne hospodarstvo Ukrainskoi RSR. Statystychnyi shchorichnyk. 1957 rik [People's economy of the Ukrainian SSR. Statistical Yearbook. 1957]. K.: Derzhstatvydav, 1958. 254 s. [in Ukrainian].

Svorak, 1998 - Svorak S.D. Narodna osvita u zakhidnoukrainskomu rehioni: istoriia ta etnopolityka (19441964 rr.) [Public education in the Western Ukrainian region: history and ethnopolitics (1944-1964)]. Kyiv: Pravda Yaroslavychiv, 1998.239 s. [in Ukrainian].

Stefaniuk, 2002 - Stefaniuk H. Ukrainska shkola v politychnykh planakh nimetskoi okupatsiinoi administratsii v 1941-1944 rr. [Ukrainian School in the Political Plans of the German Occupation Administration in 1941-1944]. Liudyna i polityka. 2002. № 2. pp. 19-28. [in Ukrainian].

Tuman, 1941 - Tuman A. Rik roboty uchytelskoho instytutu [Year of work of the teacher's institute]. Bilshovytska pravda. 1941. № 76 (426). P. 1. [in Ukrainian].

TsDAVOVU Ukrainy - Tsentralnyi derzhavnyi arkhiv vyshchykh orhaniv vlady ta upravlinnia Ukrainy [Central State Archive of the Supreme Governance and Management of Ukraine]. [in Ukrainian].

Tsohorichni tabory, 1942 - Tsohorichni tabory molodi [Youth camps in this year]. Doroha. 1942. Ch. 10. S. 142. [in Ukrainian].

Głowacki, 1998 - Głowacki A. Sowieci wobec polaków na ziemiach wschodnich II Rzeczypospolitej [The Soviets against Poles in the eastern territories of the Second Polish Republic]. Wydanie II. Lódź: Wydawnictwo Uniwersytetu Lódźkiego, 1998. 695 s. [in Polish].

Bonusiak, 2006 - Bonusiak W. Polityka ludnościowa i ekonomiczna ZSRR na okupowanych ziemiach polskich w latach 1939-1941 ("Zachodnia Ukraina" i "Zachodnia Białoruś') [Population and economic policy of the USSR in the occupied Polish territories in the years 1939-1941 ("Western Ukraine" and "Western Belarus")]. Rzeszów: Wyd-wo Uniwersytetu Rzeszowskiego, 2006. 475 s. [in Polish].

Отримано 10.04.2018 